\title{
Konsistensi Penyelenggaraan RRI dan TVRI sebagai Lembaga Penyiaran Publik
}

\author{
Atie Rachmiatie \\ ABSTRACT \\ Broadcasting Act No. 32/2002 has transformed Radio Republik Indonesia (RRI) and Televisi \\ Republik Indonesia (TVRI) from a state-owned-body to public-broadcasting-service. This \\ research aimed to investigate the impacts experienced by those two organizations concerning \\ their philosophies, role, functions, and its implementation on operational levels. Utilizing case \\ studies in West Java and South Sulawesi (Makasar), it is found that broadcasting dynamics in \\ both area are highly dynamic. On the level of normative, both are consistent enough. But on the \\ level of empirical implementation, there were still many obstacles. Although institutional \\ structure relatively proportional, this research found that local autonomy spirit is rarely
}

Kata kunci: RRI, TVRI, lembaga penyiaran publik, semangat otonomi daerah

\section{Pendahuluan}

\subsection{Latar Belakang}

Istilah radio atau televisi publik dikenal secara formal sejak tahun 2002 melalui Undang-Undang Penyiaran nomor 32/2002. Produk hukum ini merupakan pencerminan dari sistem politik dan pemerintahan di Indonesia. Diketahui bahwa dalam era Orde Baru, posisi media harus mendukung dan digunakan untuk kepentingan pemerintah dan sekelompok partai yang sedang berkuasa. TVRI dan RRI sebagai milik negara dipersepsikan hanya milik pemerintah. Padahal, negara bukan hanya pemerintah, tapi termasuk legislatif, yudikatif, dan masyarakat sebagai warga negara yang punya hak atas pelayanan dan diperhatikan kepentingannya. Ketika itu, sebagai "pemain tunggal" dalam penyebaran informasi, TVRI dan RRI telah berhasil "menyeragamkan" pemikiran, sikap, dan suatu "budaya" bangsa Indonesia. Hal ini jelas, menjadi kondisi yang tidak sehat manakala realitasnya kita ada pada kemajemukan agama, etnik, bahasa, dan budaya secara luas.

Kebijakan pemerintah tahun 80-an dengan membuka 'kran' televisi swasta memasuki Indonesia, ternyata sangat rentan menghapus tradisi, pola pikir, sikap, dan perilaku masyarakat yang selama ini dimiliki bangsa Indonesia. Betapa cepat TV-TV swasta melakukan perubahan tersebut. Sebagian besar masyarakat sudah menyadari, bahkan 'berteriak' tidak rela, melihat perubahan, terutama pada generasi muda yang kehilangan identitas budaya (jati diri)-nya. Namun, suara "silent mayority" ini seolah hanya angin sayup-sayup yang tidak mendapat respons dari pelaku penyiaran. 
Salah satu harapan masyarakat yang prihatin dengan kekuasaan kapitalis yang menciptakan hedonisme dan konsumsi tingkat tinggi ini, ada pada TV dan radio publik. Terdapat celah kosong kebutuhan publik akan informasi yang bermanfaat dan bisa digunakan untuk menjalankan kehidupan sehari-harinya.

"Ruh" radio dan televisi publik jelas tampak dalam UU 32/2002 tentang pengertian Lembaga Penyiaran Publik (LPP), adalah dimiliki oleh badan hukum negara, bersifat independen, netral, tidak komersial dan berfungsi memberikan layanan untuk kepentingan masyarakat. Dengan demikian, keberadaan media publik, baik di tingkat pusat maupun daerah, semangatnya tidak untuk digunakan untuk kepentingan pejabat pemerintah, tapi, sekali lagi, harus mengabdi pada kepentingan masyarakat.Walaupun secara psikologis dan dalam sebuah alur sistem merupakan hal yang utopis; namun bukan berarti karakter radio dan TV publik seperti di atas tidak dapat direalisasikan.

Walaupun terdapat sejumlah hambatan dan kerumitan permasalahan yang dihadapi oleh RRI dan TVRI sebagai lembaga penyiaran publik, kiranya jika mencoba mengurai 'benang kusut," maka masalah yang diidentifikasi di antaranya: Pertama, terkait dengan sistem penyiaran secara makro dan mikro; makro terkait dengan sistem politik, sistem ekonomi, dan sistem kenegaraan lainny; sedangkan mikro, terkait secara internal kelembagaan dalam penyelenggaraan lembaga penyiaran seperti masalah SDM, masalah aturan atau regulasi, serta kebijakan, masalah pendanaan, masalah teknis, program, dan isi siaran. Kedua, semua aspek internal dan eksternal satu sama lain saling memengaruhi, di mana muaranya pada performance content dan citra dari lembaga penyiaran tersebut berdasarkan isi dan penyajian siaran yang disuguhkan kepada khalayak.

Secara umum, permasalahan yang dihadapi oleh radio dan televisi publik, baik dalam konteks nasional, regional, maupun lokal, di antaranya sebagai berikut.

(1) Perubahan struktur kelembagaan penyiaran publik, belum diikuti dengan perubahan lain secara kelembagaan (SDM, dana, fungsi) termasuk menyamakan persepsi di kalangan eksekutif, legislatif, baik secara horisontal maupun vertikal (pusat, provinsi, maupun kota/kabupaten)

(2) Kemajemukan budaya sebagai potensi (kekayaan) bangsa yang tidak diakomodir dengan akurat (berdasarkan riset) oleh lembaga penyiaran publik di masing-masing daerah.

(3) Perbedaan persepsi dan "menerjemahkan" konsep arah, tujuan, peran, dan fungsi dalam sistem penyiaran di Indonesia masih tampak; terutama pada elit politik dan penguasa yang menggunakan media publik untuk menjalankan kepentingannya.

(4) Profesionalisme dan komitmen SDM di lembaga penyiaran publik yang belum kuat karena berbagai faktor yang melatarbelakanginya.

(5) Aturan/regulasi yang belum mapan, belum berpihak pada kepentingan publik, serta kebijakan internal yang belum mendukung penyelenggaraan media publik secara ideal.

Berdasarkan pemaparan di atas, maka masalah yang perlu dikaji dirumuskan sebagai berikut:

"Sejauhmana konsistensi RRI dan TVRI dalam menjalankan peran dan fungsinya sebagai lembaga penyiaran publik (Kasus RRI dan TVRI di Jabar dan Makasar)?”

\subsection{Identifikasi Masalah}

(1) Bagaimana posisi atau kedudukan LPP dalam menjembatani antara kepentingan publik dengan pemerintah?

(2) Bagaimana dukungan aturan atau regulasi penyelenggaraan LPP yang terkait dengan peran dan fungsinya?

(3) Bagaimana profil program dan acara RRI dan TVRI setelah perubahan status menjadi LPP?

(4) Faktor-faktor apa yang menjadi penghambat dalam penyelenggaraan lembaga penyiaran publik? 


\subsection{Tujuan Pembahasan}

(1) Untuk memperoleh kajian tentang Posisi atau kedudukan LPP dalam menjembatani antara kepentingan publik dengan pemerintah.

(2) Untuk memperoleh data dan informasi tentang dukungan aturan atau regulasi penyelenggaraan LPP yang terkait dengan peran dan fungsinya.

(3) Untuk mengetahui tentang profil program dan acara RRI dan TVRI setelah perubahan status menjadi LPP.

(4) Untuk mengetahui tentang faktor-faktor apa yang menjadi penghambat dalam penyelenggaraan lembaga penyiaran publik.

\subsection{Metode Penelitian}

Metode penelitian yang digunakan adalah metode kualitatif dengan jenis penelitian studi kasus, oleh karena wilayah Jawa Barat (Bandung) dan Sulawesi Selatan (Makasar) merupakan wilayah yang memiliki dinamika penyiaran yang tinggi. Teknik pengumpulan data dilakukan melalui wawancara mendalam pada informan key, yaitu: (1) Kepala Stasiun RRI Bandung; (2) Kepala Stasiun TVRI Jawa Barat; (3) Kepala Stasiun RRI Makasar; (4) Kepala Stasiun TVRI Makasar

\section{Tinjauan Teoretis}

\subsection{Konsep dan Karakteristik Media Penyiaran Publik}

Penyiaran publik adalah penyiaran yang dimiliki publik, yakni negara, pemerintah, atau organisasi publik sebagai tandingan dari kepemilikan swasta. Penyiaran ini di dalamnya mengandung 'layanan publik' berupa penyebarluasan program kepentingan dan minat publik, seperti pendidikan, budaya, atau informasi yang membantu masyarakat dalam kehidupan sehari-hari (Asia-Pacific Broadcasting Union, 1999). Konsep yang digunakan adalah, media audience as public bukan berarti sebagai konsumen. Khalayak sebagai warga negara harus di reform, dididik, diberitahu, dan tentu dihibur. Pendeknya; "dilayani” kiranya memungkinkan mereka untuk menampilkan hak dan tugasnya secara demokratis. Dalam konteks ini penyiaran tidak berkepentingan dengan hedonisme konsumen (penyiaran komersial).

Berbeda dengan TV swasta, konsep ketika memandang khalayak adalah, audience as market. Media komersial mentransfer informasi yang bermakna kepada warga negara hanya sebagai kepentingan pendukung. Tujuan utamanya

\section{Perbedaan Filosofis Lembaga Penyiaran Pemerintah dan LPP}

\begin{tabular}{|c|c|}
\hline Lembaga Penyiaran Pemerintah & Lembaga Penyiaran Publik (LPP) \\
\hline $\begin{array}{l}\text { (1) Fungsinya cenderung "voice of } \\
\text { government".....efek analisis.... program } \\
\text { mengangkat citra yang berkuasa } \\
\text { (2) Informasi tentang visi dan misi pemerintah, } \\
\text { sehingga masyarakat paham dan mendukung; } \\
\text { alurnya "top down" } \\
\text { (3) Dalam konteks kehumasan lembaga penyiaran } \\
\text { menyampaikan visi, misi, dan kebijakan } \\
\text { Pemerintah. }\end{array}$ & $\begin{array}{l}\text { (1) Fungsinya menyuarakan kepentingan } \\
\text { publik (need assessment public). } \\
\text { (2) Idealnya informasi tentang pembangunan } \\
\text { direncanakan pemerintah dan masyarakat; } \\
\text { isu muncul dari rakyat "bottom up." } \\
\text { (3) Efektif ketika pemerintah memberikan } \\
\text { kesempatan masyarakat mulai dari grass root, } \\
\text { untuk mengangkat dan membahas isu lalu } \\
\text { publik menginterpretasikan sesuai dengan visi } \\
\text { dan misi pemerintah yang terkait. }\end{array}$ \\
\hline
\end{tabular}




\section{Perbedaan Lembaga Penyiaran Publik dan Komersial}

\begin{tabular}{|c|c|}
\hline Lembaga Penyiaran Publik & Lembaga Penyiaran Komersial \\
\hline $\begin{array}{l}\text { Ide awal publik atau warga negara punya hak \& } \\
\text { kebutuhan program "lebih bermanfaat", seperti: } \\
\text { (1) program pendidikan yang instruksional } \\
\text { (2) program tentang kedalaman \& keteguhan } \\
\text { agama serta budi pekerti } \\
\text { (3) program budaya \& tradisi serta kearifan lokal } \\
\text { (4) program yang membuka diskusi dengan } \\
\text { argumen yang baik dan pencarian solusi } \\
\text { (5) program untuk meningkatkan apresiasi } \\
\text { terhadap kemajemukan,dll }\end{array}$ & $\begin{array}{l}\text { (1) Nafas atau 'semangat'nya untuk tujuan } \\
\text { komersial/keuntungan finansial } \\
\text { (2) Memiliki keyakinan bahwa penonton suka } \\
\text { hiburan, film, musik, drama, kuis-kuis \& } \\
\text { program yang gemerlap dengan selebriti dan } \\
\text { hadiah } \\
\text { (3) Lebih mendahulukan aspek hiburan dan } \\
\text { komersial } \\
\text { (4) Program pelayanan publik biasanya hanya } \\
10 \% \text { dari keseluruhan program }\end{array}$ \\
\hline
\end{tabular}

membuat konsumen sadar tentang produk dan jasa dan mengikat perhatian mereka dengan program hiburan. Komunikasi ini efektif selama audiens memberi perhatian kepadanya tanpa menghiraukan pengaruhnya sebagai warga negara. Pembedaan antara audience as public (citizen) dan audiens as market (consumers) penting untuk penyiaran yang akan berkiprah di pelayanan publik.

\subsection{Karakter Lembaga Penyiaran Publik}

Berdasarkan perbedaan di atas, maka lembaga penyiaran publik memiliki karekteristik yang khas, di antaranya.

(a) Punya visi untuk memperbaiki kualitas kehidupan publik, bangsa, dan hubungan antarbangsa

(b) Punya misi untuk menjadi forum diskusi, artikulasi, dan pelayanan kebutuhan publik

(c) Ada pengakuan signifikan terhadap pengawasan dan evaluasi oleh publik sebagai khalayak dan partisipan yang aktif.

Sebagai konsekuensi dari sebuah LPP dan ia berbeda dengan lembaga penyiaran swasta atau komunitas, terdapat indikator yang khas, di antaranya:

(a) Akses publik: didirikan tidak hanya berdasarkan potensi ekonomi, namun dengan pertimbangan pemerataan informasi; misalkan daerah terpencil/blank spot.

(b) Dana publik: menggunakan dana pemerintah dalam bentuk APBN (tingkat nasional) dan APBD (tingkat daerah).

(c) Akuntabilitas publik: mempertanggung jawabkan program dengan ukuran moral dan tata nilai publik (moral accountability); mempertanggungjawabkan keuangan (financial accountability)

d) Keterlibatan publik: ada kerjasama seluasluasnya dengan berbagai kelompok di masyarakat, mengundang serta menyambut keterlibatan publik.

\subsection{Peran-peran LPP: Harapan dan Realitas}

Secara eksplisit, dalam UU 32/2002 dikemukakan bahwa asas penyiaran, yaitu manfaat, adil dan merata, kepastian hukum, keamanan, keberagaman, kemitraan, etika, kemandirian, kebebasan dan tanggung jawab. Kemudian, tujuan penyiaran di Indonesia adalah untuk memperkukuh integrasi nasional, terbinanya watak dan jati diri bangsa yang beriman dan bertakwa, mencerdaskan kehidupan bangsa, memajukan kesejahteraan umum, dalam rangka membangun masyarakat yang mandiri.

Asas dan tujuan ini tidak hanya berlaku untuk 
radio dan televisi publik, namun berlaku juga untuk semua bentuk penyiaran, termasuk radio dan televisi swasta. Di sisi lain, asas dan tujuan di atas memang perlu penjabaran untuk bisa diaplikasikan, karena dianggap merupakan konsep yang bersifat abstrak. Untuk itu diperlukan suatu pemahaman, kesepakatan dan komitmen dari semua pelaku penyiaran untuk bisa mewujudkannya.

Michael P McCauley (2003) optimis bahwa peran media radio dan televisi cukup tinggi untuk menumbuhkan partisipasi masyarakat dalam sistem politik yang demokratis. Ada tiga peran radio dan televisi untuk mendekatkan gap yang bisa menguntungkan atau tidakyang dilakukan oleh politik ekonomi bangsa, yaitu (1) usaha untuk menjamin informasi tentang agenda politik, dalam tingkat dan bentuk yang tepat dan merefleksikan secara akurat dalam bentuk pengetahuan yang baik, mudah dan universal diterima semua warga negara; (2) usaha untuk menolong warga negara untuk berpartisipasi dengan cara yang tepat dalam diskusi politik; (3) usaha untuk menjamin warga negara memengaruhi selektivitas subjek informasi yang tersedia.

Public Service Broadcasting di Inggris menekankan empat area yang harus dimiliki oleh sebuah lembaga penyiaran publik yaitu:(1) kualitas program; (2) nilai-nilai sosia;. (3) keragaman program; (4) kisaran dan keseimbangan program. Maka itu, kunci program pelayanan informasi publik untuk radio dan televisi publik areanya adalah : pendidikan, peliputan politik, berita, seni, keagamaan, dan representasi dari berbagai kelompok sosial (Bignell \& Orlebar, 2005 :14).

\section{Temuan Penelitian dan Pembahasan}

Perubahan status TVRI menjadi Lembaga Penyiaran Publik (LPP) sesungguhnya dapat menjadi media alternatif bagi proses pencerahan dan pencerdasan bangsa, serta membuka peluang untuk menyatakan eksistensinya di tengah-tengah kehidupan masyarakat yang berada dalam tekanan media yang bersifat komersial (Cetak Biru TVRI, 2006-2011: 8-9).

Posisi atau kedudukan RRI dan TVRI sebagai LPP sangat strategis untuk menjembatani antara kepentingan pemerintah dengan masyarakat.
Pemerintah secara ideal berperan sebagai fasilitator, policy, dan pengawasan terhadap peran komunikasi dan informasi.

Selain itu, yang juga sangat penting, adalah memberikan kesejahteraan terhadap warganya. Namun, pada saat ini negara tidak bisa memberikan jaminan harapan kepada rakyat (rakyat tidak merasakan perlindungan dari pemerintah). Untuk itu, diperlukan kesamaan persepsi dan komitmen atas tujuan bernegara bagi semua pihak yang dapat diakselerasi melalui komunikasi, informasi, dan media massa. Kecenderungan lain, pada saat ini ada pergeseran kekuasaan eksekutif, dari yang "powerfull" menjadi lebih terbagi dan t ampak ada dominasi kekuasaan legislatif. Konsekuensinya pada isi media massa, cenderung pada saat ini banyak media yang tidak peduli lagi terhadap kegiatan pemerintah dan lebih banyak mengekspos kegiatan masyarakat yang tidak proporsional.

Berikut ini gambaran tentang konsistensi RRI dan TVRI dalam penyelenggaraannya sebagai lembaga penyiaran publik.

\subsection{Kasus RRI Makasar}

Posisi atau kedudukan RRI dalam menjembatani antara kepentingan publik dengan pemerintah, bagi RRI Sulawesi Selatan atau Makasar sudah dijalankan sejak dulu. Namun dengan perubahan kelembagaan, maka fungsi kepentingan publik mendapat porsi yang lebih besar. Sebagai contoh, kebijakan pemerintah di bidang ekonomi, kesehatan dll, RRI turut menyosialisasikannya kepada masyarakat. Komitmen RRI terhadap publik diwujudkan dalam bentuk paket-paket siaran yang hampir 50\% - 50\% memberi porsi kepentingan rakyat dan kepentingan pemerintah. Sebagai contoh, RRI Makasar seringkali dijadikan ajang tempat demo/ komplain masyarakat tentang apa pun yang menjadi isu publik; dan tokoh-tokoh masyarakat meminta agar RRI dijaga independensinya.

Selama ini, pimpinan menganggap tidak ada tekanan dari pemerintah daerah. Sebagai LPP, RRI sudah mengakses kepentingan publik melalui kerjasama dengan KPUD (Komisi Pemilihan Umum 
Daerah) dan KPID (Komiai Penyiaran Indonesia Daerah) dalam sosialisasi pilkada, oleh karena saat ini Makasar sedang menghadapi pemilihan gubernur.

Aturan atau regulasi (UU Penyiaran dan PP nomor 11 dan 12 tahun 2005) saat ini dianggap kondusif untuk menjalankan peran dan fungsi RRI sebagai lembaga penyiaran publik. Demikian pula dengan kebijakan internal RRI yang memberi keleluasaan bagi daerah untuk merancang dan menyajikan program siaran yang sesuai dengan kebutuhan masyarakat setempat.

Visi misi RRI di Indonesia bagian timur ini sangat strategis untuk membuat NKRI tetap utuh. RRI membuat program siaran berbahasa Bugis, dan ini berjaringan sampai di Natuna, Tahuna Sulsel, Filipina, Tanjung Parang, Lolesenare, Laut Cina. Stasiun produksi ada 59 stasiun, juga di daerah blank spot ada stasiun relay/pemancar penerima yaitu di: Mamuju, Buno, Sopeng, Bantaeng. Dalam menjalankan fungsi informasinya, RRI memanfaatkan juru penerang (Jupen) di berbagai wilayah sebagai narasumber yang melaporkan berbagai program dan kejadian yang ada di daerahnya. Jadi, ia berperan sebagai informan publik. Peran RRI di daerah terpencil, juga secara individual sangat berarti. Contohnya, jika transportasi atau penyampaian informasi berita keluarga dalam bentuk lain memerlukan waktu dan ruang yang sangat lama, namun melalui radio hanya sekejap sudah sampai pada tujuan. Jadi, RRI berperan sebagai layanan masyarakat

Setelah berubah status kelembagaan RRI menjadi radio publik, tampak belum ada perubahan yang berarti, baik dari segi program maupun isi siaran. Acara yang dianggap berhasil adalah dialog interaktif, oleh karena melibatkan sebanyak mungkin pendengar, sehingga mereka merasa memiliki dan mendorong untuk terus berpartisipasi aktif. Untuk itu, ada porsi-porsi isi siaran berdasarkan fungsi, tujuan, dll. Content siaran RRI saat ini sudah mencapai 40-50\% muatan lokal, sehingga kebutuhan informasi masyarakat lokal, umumnya sudah dapat terpenuhi.

Hambatan yang dirasakan sebagai radio publik, yaitu, biaya produksi dan operasional mahal; oleh karena RRI Makasar ini merupakan koordinator wilayah 7 seluruh Sulawesi dan Maluku dengan posnya di Makassar. Bisa dibayangkan luasnya wilayah kerja. Salah satu "koordinasinya" adalah tiap pukul 19.00, malam ada siaran berjaringan. Di sisi lain, anggaran APBN dan APBD kecil; namun acara siaran keagamaan tetap dijalankan. Acara ini membaca kondisi demografi di sini yang mayoritas Muslim, sehingga acara seperti, "titipan Ilahi” dan "Pesantren udara" dibuat dan ternyata banyak penggemarnya.

Kondisi manajemen keuangan, antara RRI Pusat dan Provinsi seperti berikut : Iklan terpusat dari Jakarta; ada media order yang disampaikan dari penghasilan daerah ke pusat, untuk kemudian dari pusat didistribusikan ke daerah-daerah berdasarkan usulan daerah. Namun selain ini memperpanjang birokrasi, juga pembagian dana ini dirasakan kurang proporsional, dibandingkan dengan kontribusi daerah secara finansial maupun nonmaterial (seperti memelihara integrasi NKRI, menjaga opini publik agar prodemokrasi, pendidikan politik, dsb).

Untuk kondisi manajemen SDM bahwa pegawai RRI saat ini dalam status PNS ada sekitar 264-297 orang; pemberitaan 40 orang, siaran 60 orang; usia rata-rata 40 tahun. Kondisi ini terlalu gemuk untuk sebuah lembaga yang menuntut kedinamisan, di samping terlalu "tua" untuk sebuah broadcasting yang memerlukan SDM muda yang segar dan kreatif. Hambatan lain adalah pemeliharaan alat-alat/perangkat teknis. Maintenance-nya sulit dan mahal, contohnya, tidak beroperasinya $\mathrm{OB}$ van karena mahalnya suku cadang, dll.

\subsection{Kasus RRI Jawa Barat}

Kondisi kemajemukan budaya Indonesia menjadi pisau bermata dua, ia bisa merupakan kendala untuk menjalin persatuan, tapi bisa juga bisa dipandang sebagai suatu potensi atau kekayaan bangsa. Pandangan yang kedua inilah justru yang harus diyakini oleh semua pelaku penyiaran publik, bahwa "Culture is our business “(MT Zen, guru besar ITB,2006). Sekali lagi diversity of ownership dan diversity of content, jadi 
mutlak dengan kondisi keberagaman di Indonesia. Kondisi kemajemukan budaya sebagai potensi (kekayaan) bangsa selama ini tidak diakomodasi oleh RRI. Padahal dengan kewenangan dan jaringannya ke daerah-daerah, jauh lebih memungkinkan dibandingkan dengan radio swasta, artinya peluang tersebut lebih dulu dimiliki RRI.

Masalah aturan atau regulasi serta kebijakan. Regulasi ini bisa dilihat sebagai peluang, karena dari kuantitas alokasi frekuensi, UU memberikan $20 \%$ untuk media publik dari seluruh frekuensi di wilayah tersebut. Aturan sekarang dianggap lebih bagus, karena tidak ada lagi pengekangan dan banyak diberikan kebebasan. Tapi aturan perlindungan terhadap wartawan masih kurang dan sistem pertanggungjawaban masih lemah.

Secara mikro, terkait secara internal kelembagaan dalam penyelenggaraan penyiaran seperti masalah SDM, dimana masih tersisa mental PNS yang birokrasi dan feodal serta tidak independen, menjadikan RRI gemuk, lamban dan tidak efisien. Kondisi pendanaan akan terkait dengan teknis yang menyangkut kualitas alat serta pada program dan isi siaran. Semua aspek internal dan eksternal satu sama lain saling mempengaruhi, dimana muaranya pada performance content dan citra RRI yang semakin redup di tengah-tengah gemerlapnya radio-radio swasta.

Dalam menjalankan Peran sebagai pelestari budaya, bagi RRI masih ada perbedaan persepsi. Budaya "diterjemahkan" dalam penyiaran hanya dalam bentuk kesenian. Penggalian nilai-nilai, pola pikir, pola perilaku dalam kehidupan sehari-hari etnik tertentu belum diwujudkan dan dikemas dengan menarik. Tradisi dan kearifan lokal yang dimiliki budaya kita selama bertahun-tahun, sudah lama ditinggalkan terutama oleh masyarakat urban. Seperti dalam mengolah tanah, mengeksploitasi sumber daya alam, sistem distribusi dan pengalokasian hasil eksploitasi. Sistem kapitalis saat ini lebih menimbulkan ketidakpuasan dari berbagai pihak, terutama masyarakat grassroot. Peran inilah yang diharapkan jadi andalan RRI untuk menyajikannya, walaupun dengan konsekuensi dana yang lumayan. Oleh karena ia harus melibatkan budayawan, peneliti, antropolog serta pelaksana teknis penyiaran yang profesional. Pencitraan bahwa nilai-nilai tradisi yang dianggap kuno, jumud dan terbelakang memang sedang digencarkan oleh kaum 'modern' yang sebetulnya, di belakang, mereka punya kepentingan bisnis kapitalisme. Untuk itu ditawarkan strategi dalam pengelolaan sumberdaya manusia, seyogyanya mempertimbangkan dan menghargai sistem pengetahuan yang terkandung dalam nilai-nilai budaya lokal (Kusnaka, 2005).

Program interaktif seperti "Debat Remaja" meliputi isu-isu penting tentang pendidikan, reproduksi, dan lain-lain Program RRI saat ini banyak menampung aspirasi masyarakat tentang politik dan demokrasi melalui, antara lain, nama program siarannya adalah gentra harmoni pagi dan aspirasi parahiyangan. Program siaran semuanya bertujuan menjadikan RRI sebagai wisata budaya dan menampung aspirasi masyarakat tentang aturan pilkada dan calon gubernur.

Hambatan dan kerumitan masalah yang dihadapi memang seperti 'benang kusut" yang sulit diurai dari mana dulu. Namun, yang teridentifikasi di antaranya, terkait dengan sistem penyiaran secara makro dan mikro; makro terkait dengan sistem politik, sistem ekonomi dan sistem kenegaraan lainnya. Selama tidak ada 'political will' dari pemerintah pusat maupun daerah serta DPR/ DPRD untuk mengalokasikan APBN/APBD untuk RRI, maka diprediksi RRI akan masuk dalam permainan industri penyiaran yang berideologi rating. Atau tetap menjadi siaran yang tidak diminati khalayaknya karena penyajian yang tidak menarik, yang disebabkan oleh peralatan yang sudah tua, biaya produksi/operasional yang rendah, gaji yang minim dan seterusnya seperti 'lingkaran setan' yang sulit diputus rantainya.

\subsection{Kasus TVRI Jawa Barat}

Kedudukan TVRI secara kelembagaan sangat strategis untuk menjembatani kepentingan publik Jabar dengan pemerintah. Eksistensi TVRI bagi pemerintah sangat membantu dalam menyosialisasikan kebijakan/kegiatan yang dilakukan, sehingga mereka sering menyeponsori 
beberapa program acara yang terdapat di TV publik. Juga menjalin kerja sama dalam bentuk lain. Sebagai media publik, TVRI menekankan pada program siaran edukasi yang sarat dengan keagamaan dan etika, seperti memberi porsi yang cukup untuk siaran dakwah dan mengeliminir berita kriminal.

Dukungan regulasi disikapi oleh Kepsta TVRI Jabar bahwa UU Pers dan Penyiaran secara positif karena dianggap sudah komprehensif, terutama dengan adanya perlindungan terhadap nara sumber. Akan tetapi, dalam aplikasinya masih dirasakan kurang. Hal ini disebabkan oleh kurangnya integrasi dalam sosialisasi antara pihakpihak yang berwenang. TVRI sebagai sebuah media publik tidak merasakan adanya hambatan dari aturan-aturan dalam UU Pers dan Penyiaran tersebut bagi mereka untuk menjalankan tugastugas di media massa. Justru TVRI menganggap aturan-aturan dalam UU Pers dan Penyiaran memberikan atmosfir kerja yang kondusif bagi mereka dalam menjalankan tugas dan fungsinya selaku praktisi media. Dalam menjalankan visi dan misinya strategi yang dilakukan oleh TVRI adalah: Balance and Cover Both Side.

Program siaran yang dihasilkan TVRI Jabar digambarkan sebagai berikut: Siaran langsung 70\% dan Outside Broadcasting 30\%. Materi siaran: 40\% Nasional dan 60\% Lokal. Dengan pembandingan porsi 4 bidang layanan secara seimbang antara Hiburan, Informasi, Edukasi dan Kontrol Sosial.

Orientasi TVRI terhadap kepentingan masyarakat dan publik tidak bertumpu pada satu segmen saja, akan tetapi harus seimbang dan proporsional di antara ke empat layanan (informatif, edukatif, hiburan, dan kontrol sosial) yang disediakan dan harus menjangkau semua lapisan masyarakat. Produk TVRI dalam mewujudkan kehidupan demokrasi di Indonesia (Jawa Barat) 3 tahun terakhir di antaranya: pilpres 2004, fit dan proper test pemilihan legislatif, parlementaria dan pilkades.

Tugas dan peran TVRI dalam mencerdaskan bangsa tampak dalam TUPOKSI-nya ketika menyusun program dan materi siaran dengan sangat selektif. TVRI bukan termasuk media industri sehingga tidak terlalu memikirkan komersialisi. Kontribusi TVRI untuk mencerdaskan bangsa dapat terlihat dari program-program yang diberikan, misalnya dalam layanan edukasi TVRI memberikan acara-acara pembelajaran lewat TV seperti matematika, bahasa indonesia, bahasa inggris, dan juga pembelajaran lainnya seperti sejarah, kebudayaan, religi yang dikemas lewat siaran pendidikan. Dalam layanan informasi, TVRI memberikan acara "Dunia dalam Berita," "Berita Pagi," "Berita Siang," dan sebagainya. Untuk layanan hiburan, TVRI memberikan berbagai sajian hiburan nasional dan lokal. Untuk layanan sosial dan politik TVRI juga menyediakan beragam acara seperti informasi seputar parlemen, perspektif, pro publik, dll.

Dalam menjalankan fungsi kelembagaan sebagai media publik, terdapat faktor-faktor pendukung dari lingkungan internal TVRI Jabar, yaitu:

(a) Sumber daya manusia yang sudah cukup terlatih dan terampil, dan hampir $90 \%$ pegawainya adalah pegawai negeri, sehingga TVRI tidak terlalu harus bersusah payah untuk memikirkan upah kerja para pegawainya.

(b) Peralatan yang dimiliki sangat memadai untuk melayani masyarakat (peralatan kanibal).

(c) Kompetitor (TV swasta nasional, TV swasta lokal). Kompetisi dengan TV-TV lainnya menjadi faktor daya dorong bagi TVRI untuk lebih struggle dan fight dalam memberikan layanannya.

Namun, di tengah-tengah potensi yang dimiliki TVRI Jabar, terdapat faktor-faktor penghambat dalam penyelenggaraan siaran, di antaranya:

(a) Anggaran yang diterima TVRI adalah anggaran pemerintah yang, tentu saja, sangat tidak memadai untuk menjalankan programprogram yang sudah dicanangkan. Untuk mengatasinya, TVRI banyak melakukan kerjasama program dengan departemendepartemen, dinas-dinas atau lembagalembaga lain; misalnya, dengan Disbudpar menyelenggarakan acara seni dan budaya 
(Bruk-brak), dengan DPRD mengadakan dialog interaktif; dengan Dinas Pendidikan menyelenggarakan Sosialisasi dan lain sebagainya. Anggaran, terutama sangat diperlukan untuk peremajaan peralatan, karena sejak 1987, banyak peralatan yang belum diperbarui.

(b) Sumber daya manusia, selain sebagai faktor pendukung, SDM TVRI juga sekaligus menjadi penghambat bila dilihat dari faktor usia, senior dan profesional, namun TVRI membutuhkan SDM yang lebih muda dan kreatif.

\subsection{Kasus TVRI Makasar}

Bagi TVRI Makasar (Sulawesi Selatan), adanya UU Penyiaran 32/2002 sudah sangat bagus, karena memberi peluang untuk daerah, televisi lokal, $\mathrm{PH}$ di daerah untuk berkembang. Namun, kenyataannya tidak jalan. Hal ini terjadi karena perkembangannya tersendat oleh TV swasta nasional yang saat ini beroperasi. Memang, TVRI untuk menjadi televisi publik cost-nya tinggi, sehingga taktik yang dilakukan di antaranya, menempatkan koresponden dan kontributor di daerah-daerah, untuk memenuhi kebutuhan informasi lokal.

Perbedaan status lembaga, sebelum dan sesudah LPP, tidak terlalu jauh. Isi siaran informasi masih banyak yang bersifat seremonial, namun sekarang lebih kritis dan berimbang. Kalau dulu ada desakan-desakan dari instansi tertentu untuk memperpanjang warta berita tentang instansinya, namun sekarang kita bisa edit dikasih pendek porsi beritanya, jika tidak ada news value-nya.

Saat ini, secara manajerial kebijakan TVRI pusat cukup fleksibel, walaupun belum optimal dalam memenuhi kebutuhan daerah. Contoh, kalau ada acara penting di daerah, acara dari nasional (TVRI) kadang-kadang bisa ditunda atau direkam terlebih dahulu. Bagi TVRI daerah, ada "wajib relay" dari TVRI pusat, sehingga "jalur aman"-nya adalah acara dari Jakarta direkam.

Acara TVRI daerah yang bersifat tentatif ada pada jam 5.00-20.00, yaitu 2 hari selasa dan minggu; dan ini bagi daerah merupakan peluang untuk acara lokal. Untuk itu, usulan untuk TVRI pusat memberikan 5 jam untuk TVRI daerah; sangat dinanti oleh pimpinan. Secara internal, kebijakan manajerial tentang alokasi waktu antara pusat dan daerah masih kurang proporsional, contoh dari 20 jam siaran, hanya 3 jam yang rutin untuk TVRI daerah. Hal ini tidak sejalan dengan semangat otonomi daerah.

Hambatan yang dirasakan bahwa dari manajemen keuangan, ada ketidakjelasan pembiayaan, terutama untuk program zero alias tidak ada, sehingga kita harus mencari solusi untuk pembiayaan tersebut. Yang ada hanya untuk gaji pegawai saja. Saat ini TVRI Ujung Pandang untuk pegawai 300 orang merupakan hambatan lembaga, karena SDM banyak hanya untuk memproduksi 3 jam siaran saja.

Solusi dari pimpinan, di antaranya, menggali sumber dana dan materi dengan cara menjalin kemitraan untuk produksi dan ini dikonsultasikan dengan BPK (Badan Pemeriksa Keuangan) untuk Biaya direvisi atau dialihkan dari anggaran lain ke anggaran untuk produksi, tapi tidak menyalahi aturan.

Produksi siaran selama 3 jam TVRI Makasar saat ini diisi dengan siaran berita, program anak, local content, daerah (Makassar, Bugis, Mandar, Toraja); Dialog "Makassar Forum" berisi masalahmasalah budaya, kearifan lokal seminggu sekali misalnya dignity (makna martabat bagi orang Sulsel). Banyak peluang untuk program siaran TVRI misalnya, mengangkat semua unsur kelompok masyarakat di Makassar, termasuk tokoh-tokoh Cina yang membangun Makassar, bekerja sama dengan berbagai kelompok etnik yang beragam bahasa, karena mereka memang eksis di Makassar. Untuk itu motto TVRI Makasar, saling mengingatkan.

Sebagai lembaga penyiaran publik yang bertugas sebagai pelayan informasi masyarakat, TVRI Makasar sukar menghindar dari acara-acara sosialisasi dan undangan-undangan dari berbagai instansi pemerintah maupun nonpemerintah. Namun, misalnya, juru kamera yang meliput gambar-gambar harus jujur, melaporkan secara kontekstual, tidak berpihak. Contoh, ada state- 
ment dari tokoh, tapi dibelakangnya ada poster kandidat pilkada. Itu tidak boleh. Komitmen untuk pendidikan politik saat ini diwujudkan dalam bentuk membuat siaran "Profil" untuk masingmasing kandidat dalam pilkada provinsi dengan gratis (monolog) secara merata. Dialog kerjasama dengan KPUD kontrak/MOU, 2 kali sebulan sekali, ruang hukum, ruang pendidikan, kontrak pemirsa

Motto TVRI Makasar: "Media Sipakanga"; Visi: "TV warga, menuntun dan mencerdaskan, terdepan di kawasan timur Indonesia". Saat ini, pemancar TVRI merupakan bantuan Spanyol yang direalisasikan 2008 mendatang. Misi TVRI adalah mencerdaskan bangsa, dan ini diwujudkan dalam berbagai kegiatan on air dan off air

Hambatan yang dirasakan adalah dari segi teknis yang menggunakan antena UHF untuk TVRI dan VHF untuk televisi swasta. Artinya, audiens harus memasang antena 2 macam dan ini tidak semua orang mau. Jadi umumnya khalayak ketika menangkap siaran TV swasta tapi TVRI jadi tidak bisa diterima dan sebaliknya. Konsekuensinya, mereka tidak menerima informasi yang bersifat mendidik, termasuk pendidikan politik dan kenegaraan.

Komitmen terhadap kualitas SDM TVRI, ada pelatihan-pelatihan bagi mereka dan hasil pelatihan tersebut ditransmisikan pada pekerjaan masingmasing. Dari segi regulasi kepegawaian, diusulkan agar SDM di broadcasting dijadikan PNS dengan perlakuan khusus, oleh karena mereka kadangkadang jam kerjanya tidak pasti/tentu, harus standby 24 jam untuk meliput. Jadi ada fungsional khusus yang bekerja di lapangan.

Komitmen SDM braodcasting saat ini sudah bergeser dari Integritas institusional menjadi integritas profesional. Artinya, jika SDM yang sudah ahli dan berpengalaman tidak diakomodir, baik dalam bentuk imbalan maupun kesempatan berkreasi, mereka akan mencari lembaga yang bisa memenuhi kebutuhan profesi mereka. Dan saat ini di Makasar banyak TV swasta yang membutuhkannya.

\section{Simpulan dan Rekomendasi}

\subsection{Simpulan}

(1) Konsistensi penyelenggaraan RRI dan TVRI sebagai penyiaran publik, secara normatif sudah dipahami dan diupayakan oleh para pimpinannya. Namun dalam tataran empirik, masih terdapat sejumlah kendala secara internal kelembagaan dan sistem penyiaran di Indonesia yang belum kondusif untuk berpihak penuh pada keberadaan penyiaran publik. Posisi atau kedudukan RRI dan TVRI sebagai media publik secara struktur kelembagaan, relatif proporsional antara pusat dan daerah, terutama dalam alokasi program siaran, manajerial dan teknis. Namun, dalam aplikasinya, "semangat otonomi daerah" belum sepenuhnya diterapkan. Baik di Jawa Barat maupun Sulawesi Selatan, TVRI masih belum lepas dari "bayang-bayang" media pemerintah; sehingga lebih signifikan menjadi jembatan kepentingan pemerintah kepada publik daripada sebaliknya.

(2) Dukungan aturan atau regulasi penyelenggaraan siaran RRI dan TVRI yang terkait dengan peran dan fungsinya sebagai media informasi, edukasi, hiburan, dan kontrol sosial sangat memadai. Namun, masih terdapat aturan, terutama kebijakan internal, yang belum mengakomodir kebutuhan penyelenggaraan sebuah lembaga penyiaran publik.

(3) Profil program dan isi siaran RRI dan TVRI setelah perubahan status menjadi LPP tampak belum ada perubahan yang signifikan, terutama dalam pemberitaan. Adapun dalam program pendidikan dan hiburan yang bernafaskan local content masih bersifat verbalistik dan formal, belum menyentuh lebih bervariasi dan sudah menyesuaikan dengan kondisi budaya masing-masing daerah. Tampak ada perbedaan kemenarikan kemasan penyajian acara, bila dibandingkan antara TVRI dengan televisi swasta, walaupun secara substansi (materi) penting 
dan menyentuh kebutuhan publik.

(4) Faktor-faktor yang menjadi penghambat dalam penyelenggaraan lembaga penyiaran publik, baik di RRI dan TVRI Jabar maupun Makasar, hampir serupa, yaitu terkait dengan terbatasnya sumber dana, anggaran yang tidak memadai terutama untuk produksi program dan maintenance peralatan. SDM yang tidak efisien serta manajemen yang masih kaku formal dan proses birokrasi yang panjang.

\subsection{Rekomendasi}

(1) Pembenahan internal kelembagaan, dengan menegakkan struktur yang lebih luwes dan ramping, kebijakan lebih terdesentralisasi.

(2) Komitmen, perjuangan, dan keberanian pimpinan dan stafdalam mewujudkan visi dan misi.

(3) Profesionalisme yang terus menerus ditingkatkan.

(4) Kemitraan dengan kekuatan manapun, kelompok manapun namun tetap netral dan independen.
(5) Membentuk "benchmarking" atau "positioning" sebagai TV publik secara konsisten.

(6) Peningkatan kesadaran masyarakat atas hak, kewajiban, tanggungjawab, dan peran serta dalam penyelenggaraan penyiaran publik.

\section{Daftar Pustaka}

Bignell, Jonathan \& Orlebar Jeremy. 2005. The Television Handbook, Routledge taylor \& Francis Group, London \& New York.

Cetak Biru Kebijakan Umum, Pengembangan Kelembagaan dan Sumber Daya TVRI. 20062011. TVRI Pusat, Jakarta.

M.T.Zen. 2006. Seminar "Peran Media Massa dalam Pembentukan Jati diri Bangsa” Institut Teknologi Bandung.

Kusnaka Adimiharja. 2005. Semiloka "Tanggungjawab Sosial Lembaga Penyiaran di Jawa Barat", KPID Jabar, Bandung.

Undang-Undang Penyiaran nomor 32 tahun 2002. 
